\title{
Cytokines profile in knee cartilage of rats during monoiodoacetate- induced osteoarthritis and administration of probiotic
}

\author{
O. H. Korotkyi, A. A. Vovk, T. I. Halenova, T. B. Vovk, K. O. Dvorshchenko, \\ T. M. Falalyeyeva, L. I. Ostapchenko \\ Educational and Scientific Center "Institute of Biology and Medicine", \\ Taras Shevchenko National University of Kyiv \\ 64/13, Volodymyrska Str., Kyiv, Ukraine, 01601 \\ korotky@ukr.net
}

\begin{abstract}
Aim. To identify the effect of probiotic (PB) on cytokines profile in knee cartilage of rats with experimental osteoarthritis (OA). Methods. The animals of $1^{\text {st }}(\mathrm{Control})$ and $3^{\text {rd }}(\mathrm{PB})$ groups got $50 \mu \mathrm{L}$ of saline to both hind knees. The animals of $2^{\text {nd }}$ (MIA-OA) and $4^{\text {th }}$ groups (MIAOA-PB) got single injection of $1 \mathrm{mg}$ monoiodoacetate (MIA) dissolved in $50 \mu \mathrm{L}$ of saline to knee, after which MIA-OA developed for 28 days. PB feeding [was] provided daily for 14 days during the MIA-OA progress. The levels of cytokines (IL-1 $\beta$, TNF- $\alpha$, IL- 6 , IL- 8 , IFN- $\gamma$, IL-4, IL-10, TGF- $\beta$, IGF-1) were measured in cartilage homogenates by [the] enzyme-linked immunosorbent assay (Biotrak ELISA System, GE Healthcare, USA). Results. MIA-OA caused [an] increase in the levels of IL-1 $\beta$, TNF- $\alpha$, IL-6, IL-8, IFN- $\gamma$, IL-10, TGF- $\beta$, decreased the level of IGF-1 and did not change the level of IL-4, compared to Control. PB during MIA-OA increased the level of IGF-1, decreased the levels of IL-1 $\beta$, TNF- $\alpha$, IL-6, IL-8, IFN- $\gamma$, TGF- $\beta$, compared to MIA-OA, but did not reach the Control values (unlike IL-4 and IL-10 that equaled to Control). Conclusions. MIA-OA caused significant changes in the levels of studied cytokines in knee cartilage. An application of PB has positive local anti-inflammatory effect in cartilage tissue of rats with MIA-OA.
\end{abstract}

Keyw or d s: osteoarthritis, cytokines, growth factors, probiotic, cartilage.

\section{Introduction}

Osteoarthritis (OA) is a widespread pathology of the musculoskeletal system with complex etiology. This disorder strikes the movable limb joints, leading to the irreversible degeneration of cartilage, damage of joints with im- paired movement, acute pain [1]. According to different sources, from $14 \%$ to $25 \%$ of adults, 55-60 years old, have a risk of OA [2, $3]$. The development of OA is associated with the local synthesis of inflammatory mediators

(C) 2020 O. H. Korotkyi et al.; Published by the Institute of Molecular Biology and Genetics, NAS of Ukraine on behalf of Biopolymers and Cell. This is an Open Access article distributed under the terms of the Creative Commons Attribution License (http://creativecommons.org/licenses/by/4.0/), which permits unrestricted reuse, distribution, and reproduction in any medium, provided the original work is properly cited 
that transfer from the joint tissue into the bloodstream and can lead to systemic inflammatory responses [4]. Signaling pathways of cytokines play a key role in the OA development through the control of pro- /anti-inflammatory balance and the response to the synthesis of matrix metalloproteinases and ADAMTS (a disintegrin and metalloproteinase with thrombospondin motifs) through [the] degradation of extracellular matrix collagen II and aggrecan [5]. The OA-related mediators include interleukins (ILs) $-1 \alpha,-1 \beta,-1 \mathrm{ra},-6,-7$, $-8,-15,-33$, tumor necrosis factor $\alpha(\mathrm{TNF} \alpha)$, matrix metalloproteinases $-1,-2,-3,-10,-13$, -14 , C-reactive protein, chemokine ligands -5 , -8 , tissue inhibitors of metalloproteinases -1 , -2 , leptin, adiponectin and some others [6]. The investigation on cytokines as potential biomarkers for OA opens new strategies of the disease treatment [7]. Modern strategies of nonsurgical treatment of knee OA are based on efficiency of pain-reducing and functional outcomes restoring [8]. They include walking cane, biomechanical interventions, corticosteroids, nonsteroidal anti-inflammatory drugs (NSAIDs), capsaicin, paracetamol [9]. However, long-term administration of NSAIDs induces a number of side effects via nephrotoxicity, cardiovascular adverse effects, gastrointestinal toxicity [10]. Except for dyspepsia, gastroduodenal ulcers, gastrointestinal bleeding and perforation, NSAIDs alter the species diversity and stability of microbiome [11].

In clinical practice, joint diseases are mainly associated with obesity and non-alcoholic fatty liver disease. The dysbiosis of intestinal microbiota leads to obesity, insulin resistance and systemic inflammation, so it is feasible that gut microbiota is ascribed to pathogenesis of OA. The relation between OA and obesity was appointed to exceeding joint loading as a consequence of increased body weight; and yet disturbed lipid metabolism, low-grade inflammation, and adipokines on joint tissues are the former etiology for obesity-stimulated OA. Additionally, clinical and experimental studies have shown that administration of probiotics and nutraceuticals exhibited notable health benefits in obesity and corresponding diseases [12-16].

Recent studies show tight link between alteration of intestinal microbiota and pathogenesis of various disorders, such as inflammatory bowel disease, cancer, OA [17]. The risk factors of OA like gender, age, obesity, and diet are profoundly associated with intestinal microbiota via regulation of immune response, cognitive function, hormonal factors, nutrientinduced changes [18]. The possible strategies that can alter, modify and reinstate gastrointestinal microbiota are forcedly discussed in the past few decades. Most of them described beneficial effects of some probiotic (PB) strains (Bifidobacterium, Lactobacilli, S. boulardii, B. coagulans.), prebiotics and synbiotics supplements [7]. Our previous works showed promising results of $\mathrm{PB}$ administration to rats with experimental OA on cartilage remodeling [19, 20], oxidative/antioxidant balance [21] and cytokines profile of blood [22]. The PB complex included live symbiotic biomass that contains 14 strains of microorganisms belonging to 10 species: Bifidobacterium bifidum, B. longum, Lactobacillus acidophilus, L. delbrueckii, L. helveticus, Propionibacterium freudenreichii, P. acidipropionici, Lactococcus lactis, Acetobacter aceti, Streptococcus sali- 
varius. In this study, we concentrated on the effect of PB mix on the levels of some important cytokines (IL-1 $\beta$, TNF- $\alpha$, IL-6, IL-8, IFN- $\gamma$, IL-4, IL-10, TGF- $\beta$, IGF-1) in cartilage homogenates of rats during MIA-OA.

\section{Materials and Methods}

Animals and ethical statements. This study involved male non-linear white rats (weighing $180-240 \mathrm{~g}, \mathrm{n}=20$ ). All manipulations were conducted according to the general ethical principles of experiments on animals adopted by the Sixth National Congress of Ukraine on Bioethics [23], Guide for the Care and Use of Laboratory Animals [24] and approved by bioethics commission of Educational and Scientific Center "Institute of Biology and Medicine", Taras Shevchenko National University of Kyiv.

Design of experiment. The rats were randomly divided into four groups with five animals in each group and placed under standard living conditions of the vivarium. Each animal was weighed once a week to correct doses of PB. Single intra-articular injection of monoiodoacetate (MIA, Sigma, USA) to ligament medial side of hind knee was used to provide MIA-induced OA (MIA-OA) [25, 26]. The animals of $2^{\text {nd }}$ and $4^{\text {th }}$ groups got $1 \mathrm{mg}$ of MIA dissolved in $50 \mu \mathrm{L}$ of saline to right hind knee. Left hind knee got $50 \mu \mathrm{L}$ of saline only (Fig. 1). The animals of $1^{\text {st }}$ and $3^{\text {rd }}$ groups got $50 \mu \mathrm{L}$ of saline to both hind knees. The rats of $3^{\text {rd }}$ and $4^{\text {th }}$ groups got intragastric administration of PB composition (O.D. "Prolisok", Ukraine) at a dose of $140 \mathrm{mg} / \mathrm{kg}$ diluted in freshwater daily for 14 days of the experiment model. The animals of $1^{\text {st }}$ and $2^{\text {nd }}$ groups received intragastric irritation with freshwater for 14 days.

Sampling. The cartilage sampling was provided on the 30th day of the experiment after sacrificed of the animals, according to the protocol of the ethics committee. Knee joints were carefully removed and stored in plastic tubes at $-80^{\circ} \mathrm{C}$ for no more than 3 months

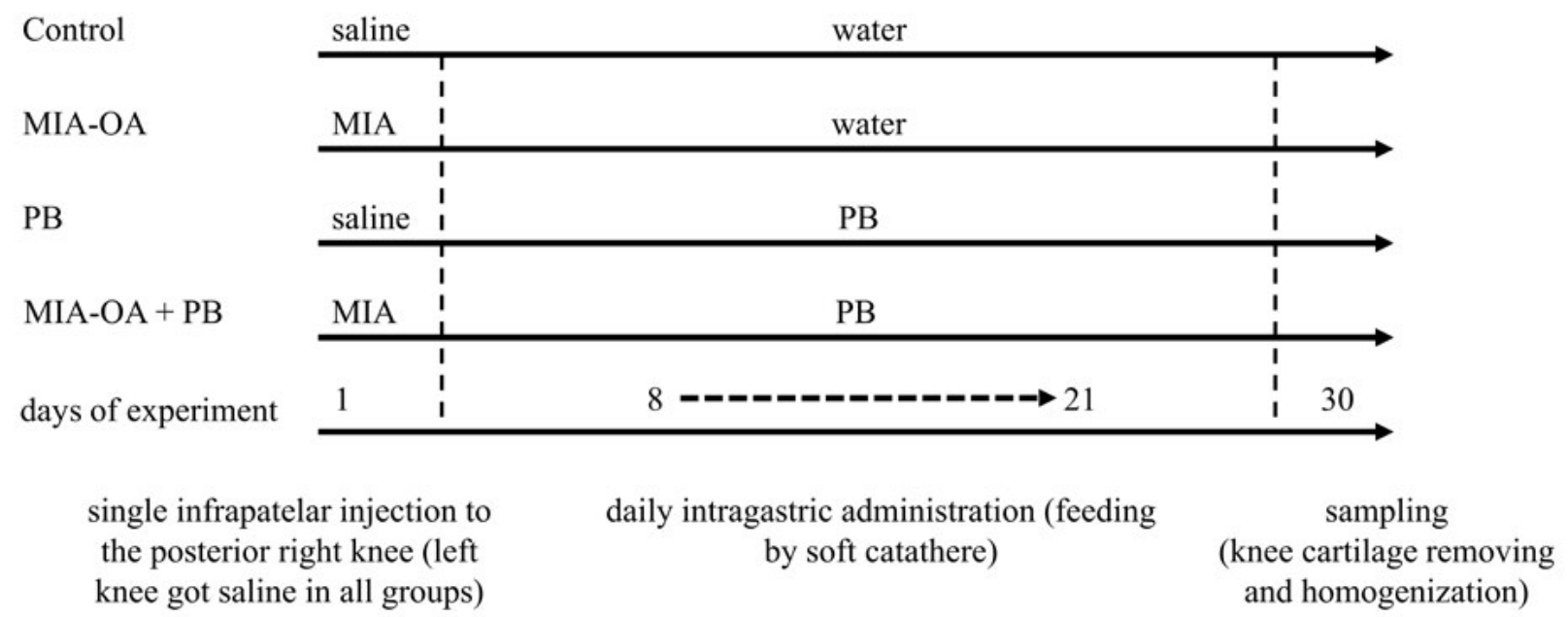

Fig. 1. Design of experiment. 
before homogenization. The joints sliced in $2 \mathrm{~mm}$ pieces and chopped in a porcelain mortar with liquid nitrogen. Then added $1 X$ PBS (Sigma, USA) in 1:10 ratio to a weight of cartilage and homogenized in automated homogenizer Ultra Sonic T10 Basic (IKA, Germany) at $3000 \mathrm{rpm}$ for $3 \mathrm{~min}$. Unhomogenized parts were removed by centrifugation on 1-15K Centrifuge (Sigma, USA) at $3000 \mathrm{rpm}$ for $15 \mathrm{~min}$. Supernatants was stored in plastic tubes for further biological tests no more than 1 week at $-20^{\circ} \mathrm{C}$.

ELISA tests. The samples were measured for total protein by the Bradford method [27, 28]. Aliquots of PBS were added to equalize total protein in each sample. The levels of the studied parameters (IL-1 $\beta$, TNF- $\alpha$, IL-6, IL-8, IFN- $\gamma$, IL-4, IL-10, TGF- $\beta$, IGF-1), were measured in prepared samples by enzyme-linked immunosorbent assay (Biotrak ELISA System, Healthcare, USA), using manufacturer's recommendations.

Statistical analysis. SPSS 23 (IBM, USA) was used to conduct statistical calculations. Normal distribution was checked via the Shapiro-Wilk test for normality and conducted to one-way ANOVA with Tukey`s post hoc test for multiple comparisons. Two-sided $\mathrm{P} \leq 0.05$ was considered statistically significant. The results were presented as average arithmetic \pm standard error meaning (SEM). GraphPad Prism 8 (GraphPad Software Inc., USA) was used to build figures.

\section{Results and Discussion}

Many studies described IL-1 as a central factor of immune disorders. It can be produced in many types of the immune cells (monocytes, macrophages, lymphocytes, synovial lining cells) and activated intracellular T-cells interactions by binding with (IL-1R) on the T-cells surface [29]. The expression of IL-1 $\beta$ is linked with the response to microbial patterns and is able to form trimolecular signaling complex with IL-1R and IL-1AcP and further to activate the pro-inflammatory cytokine expression [30]. Medical trials showed elevating of IL- $1 \beta$ in human with OA in synovial fluid, cartilage and subchondral bone layer [31]. In present study, MIA-OA caused an increase of IL-1 $\beta$ in homogenates of cartilage 2.4 times compared to Control group, (Figure 2 A). Administration of $\mathrm{PB}$ to rats without $\mathrm{OA}$ caused no significant changes in the level of IL-1 $\beta$, compared to Control group. Administration of PB to animals with MIA-OA decreased the values of IL-1 1.3 times compared to MIA-OA group though they remained 1.9 times higher than Control. The similar effect had the administration of mono-strain PB (L. casei) that decreased the level of IL- $1 \beta$ in rats with collageninduced arthritis whereas summarized effect occurs during mixture administration in rats with collagen II type [32].

IL-1 $\beta$ has a synergistic relationship in local and general inflammatory processes, mainly with TNF- $\alpha$, IL- 6 and TGF- $\beta$ that creates the key links of inflammatory response [33]. TNF- $\alpha$ has two isoforms (soluble and membrane-bound), which initiated various signal pathways and response for apoptosis, pro-inflammatory cytokine expression, inflammation and cell survival [30]. The study of platelet lysate towards MIA-OA focused on an ability to regulate TNF- $\alpha$ signal-related mechanisms considering this approach as a promising strategy of an alternative option for OA therapy [34]. In this work, MIA-OA caused an increase 
$\boldsymbol{A}$

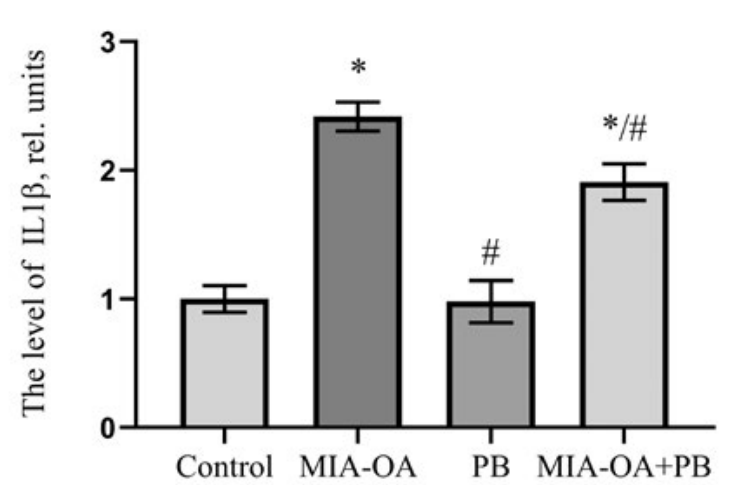

C

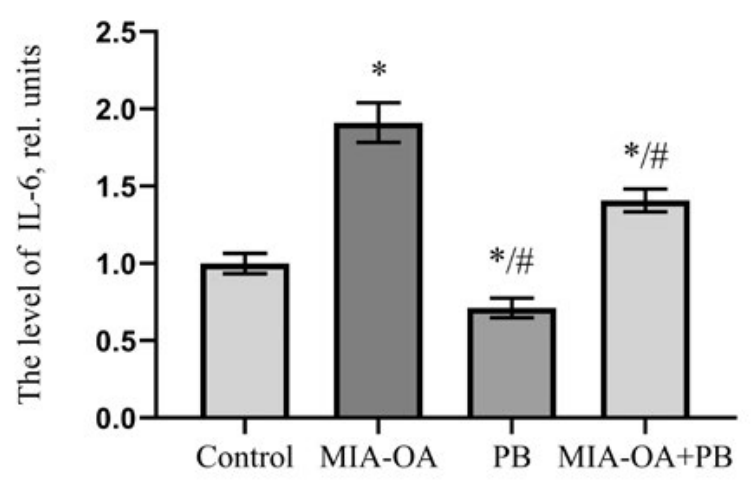

$\boldsymbol{E}$

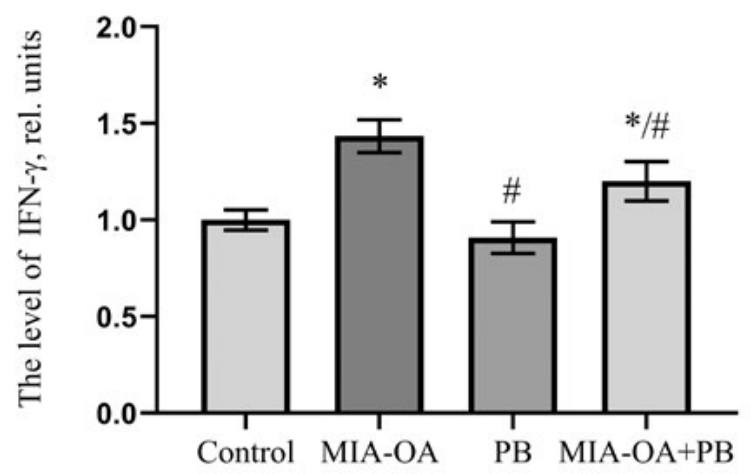

$\boldsymbol{B}$

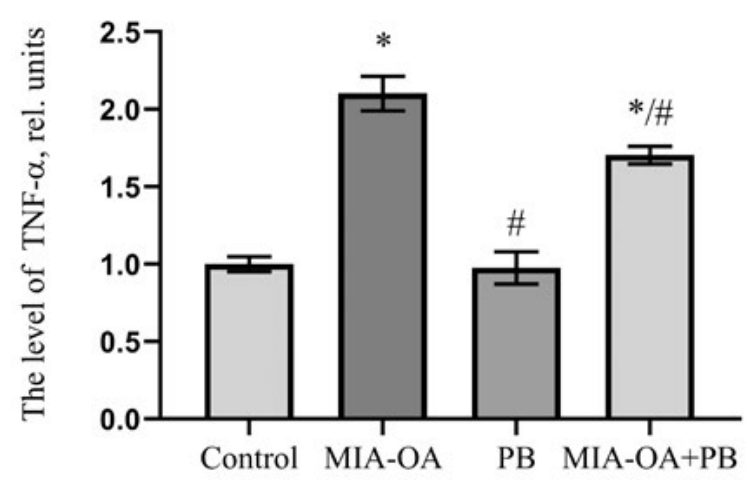

D

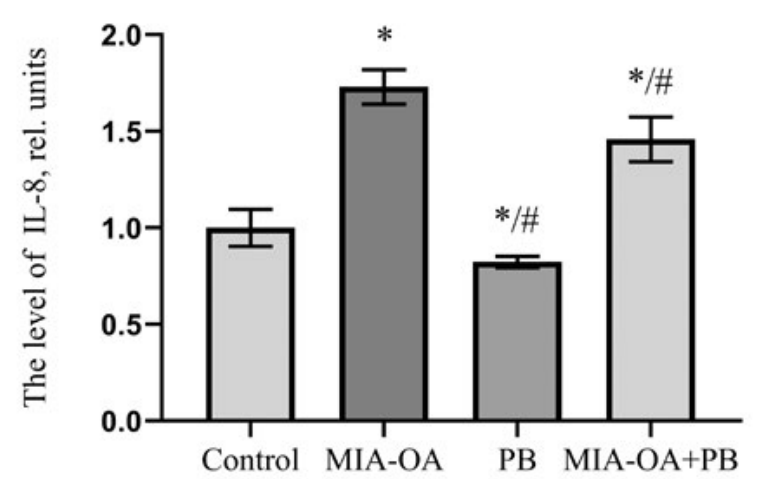

Fig. 2. The levels of pro-inflammatory cytokines IL-1 $\beta$ (A), TNF- $\alpha$ (B), IL-6 (C), IL-8 (D) and IFN- $\gamma$ (E) in homogenates of knee cartilage of rats with experimental OA and administration of $\mathrm{PB}$, rel. units ( $\mathrm{n}=5$ in each group).

Note: $* \mathrm{p} \leq 0.05$, compared to Control group; $\# \mathrm{p} \leq 0.05$, compared to MIA-OA group.

of TNF- $\alpha 2.1$ times, compared to Control group, (Fig. 2 B). The review of recent data showed that increasing soluble TNF $\alpha$ in blood serum and intracellular matrix of cartilage affected the prevalence of joint space narrowing and predict knee cartilage loss [35]. Administration of PB to animals without MIA-OA (PB group) did not cause difference compared with Control. Administration of PB to animals with MIA-OA decreased the values of TNF- $\alpha$ by 1.2 times compared to MIA-OA group but they remained 1.7 times higher than Control. Showed the effect of PB during OA in the experimental rats, which is associated with the 
triggering of production of $\mathrm{TNF} \alpha$ - in $\mathrm{CD} 4 \mathrm{~T}$ cell, synovial fibroblasts, and chondrocytes [36].

Among the immunomodulatory cytokines present in the OA joint, IL-6 and IL-8, are also considered to be pro-inflammatory, and the synthesis of both can be stimulated by IL-1 and TNF-a [37]. However, neither IL-6 nor IL-8 alone was capable of stimulating cartilage degradation directly [38]. In this study, we showed [that] MIA-OA caused an increase in the levels of IL- 6 and IL-8 in homogenates of knee cartilage by 1.9 and 1.7 times, respectively, compared to the Control group (Figure $2 \mathrm{C}, \mathrm{D}$ ). Administration of $\mathrm{PB}$ to animals without MIA-OA decreased the levels of IL- 6 and IL- 8 by 1.4 and 1.2 times, respectively, compared to Control group. Administration of PB to animals with MIA-OA decreased the levels of IL- 6 and IL- 8 by 1.4 and 1.2 times, compared to MIA-OA group, but it was 1.4 and 1.5 times higher than the values of Control group, respectively. We suggest that the modulating effect of PB may be associated with [an] indirect systemic influence due to change in the number of microbial and food metabolites, e.g. acetate, butyrate, propionate. Li and Abdollahi-Roodsaz showed that these metabolites play an important role in disorders of the musculoskeletal system [18, 39]. The investigation of acute gouty arthritis in human showed that butyrate also decreased the production of IL-1 $\beta$, IL-6, IL-8 in peripheral blood mononuclear cells from healthy donors [40]. Our results show similar downregulating of IL-6, IL-8 in rats with no MIAOA, whereas IL- $1 \beta$ and TNF- $\alpha$ were on the same level. It may be associated with different sources of synthesis of these cytokines [41].
It is generally recognized that IL- $1 \beta$ and $\mathrm{TNF} \alpha$ are the main cytokines in the early and late stages of the development of OA, whereas IL-6, IL-8 can be regulatory and IL-4, IL-10, IFN $\gamma$ are classified as inhibitory cytokines, because they may block the actions of catabolic cytokines during the inflammatory process of OA in the joint [37]. However, IFN- $\gamma$ is independent from IL- $1 \beta$ and TNF- $\alpha$ signaling, it is a part of STAT1 pathway in T-cells, increases neutrophil and monocyte functions [42], inhibits CII synthesis in articular chondrocytes [43]. The action of IFN- $\gamma$ is not restricted by syntactical intermediations; cytotoxic lysis is confined to antigenic targets. IFN- $\gamma$ is stable and active at low concentrations in extracellular media, whereas isolated lytic granules have a very weak lytic capacity [44]. We have previously shown that the administration of PB to rats on the background of hypoacidity causes increased production of IFN by thymocytes and splenocytes $[45,46]$. IFN- $\gamma$ plays important role in the development of RA, whereas the data on the rodent models of OA are controversial [47]. In this study, we showed that the level of IFN- $\gamma$ in cartilage homogenates increased in MIA-OA group 1.4 times, compared to Control (Figure 2 E). Our previous result showed an increase of IFN- $\gamma$ in blood serum during MIA-OA [22]. Administration of PB did not cause differences in the level of IFN- $\gamma$ in animals without MIA-OA (PB group) and Control. PB decreased the level of IFN- $\gamma$ in MIA-OA+PB group 1.2 times, compared to MIA-OA group, however, the value did not reach that ofControl (the latter was 1.2 times higher). These results correlated with the data of the regulation of IFN- $\gamma$ in CD4+ T cells 
during [the] MIA-OA and PB supplementation [36].

Unlike the cytokines described above, IL-4 run[s the] anti-inflammatory signal response, responsible for proliferation of $\mathrm{B}$ and cytotoxic T cells, enhances MHC II expression, stimulates IgG and IgE production [48]. That is why, IL-4 has been considered [as] therapeutic targets in many studies $[49,50]$. MIAOA did not change significantly the level of IL-4, compared to Control group, (Figure $3 \mathrm{~A}$ ). The administration of $\mathrm{PB}$ decreased the level of IL-4 in both group, with MIA-OA and without it, compared to Control group.

A

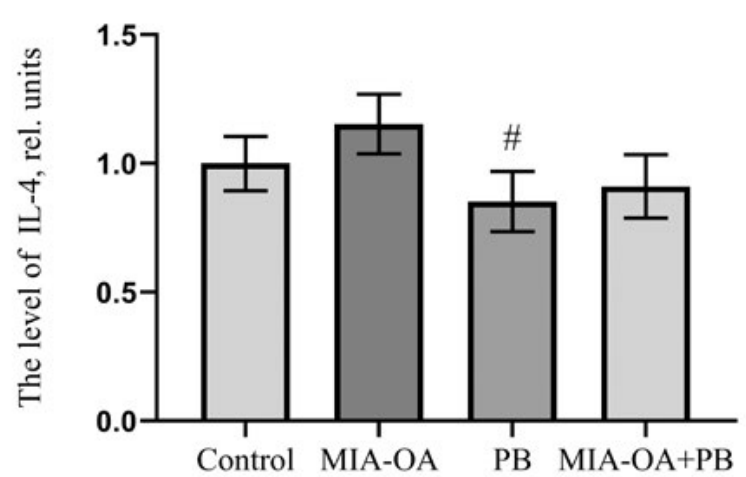

C

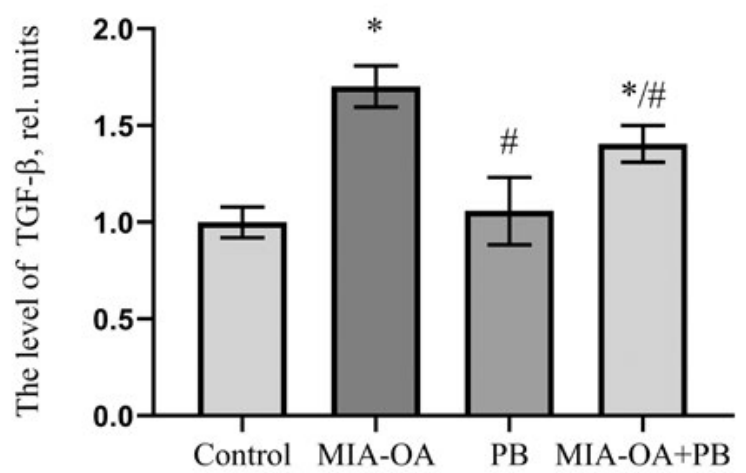

Along with IL-4, IL-10 has a strong antiinflammatory effect; its receptors are expressed on the cells of synovial tissue and chondrocytes. IL-4 and IL-10 not only reduce the synovial inflammation but also reverse the TNFalpha-induced production of prostaglandin E2 by synovial fibroblasts and inhibit the apoptosis of chondrocytes and cartilage breakdown [51]. Moreover, IL-4 and IL-10 have partially overlapping and complementary activities. The experimental models of synovial tissue cultures showed the effect of IL-10 itself on inhibition of the TNF $\alpha$ and IL- $1 \beta$ productions and a decrease of the levels of MMPs produced

$\boldsymbol{B}$

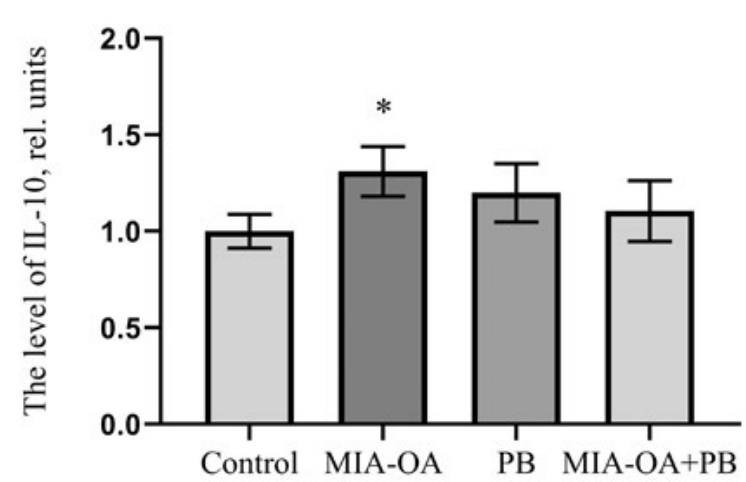

D

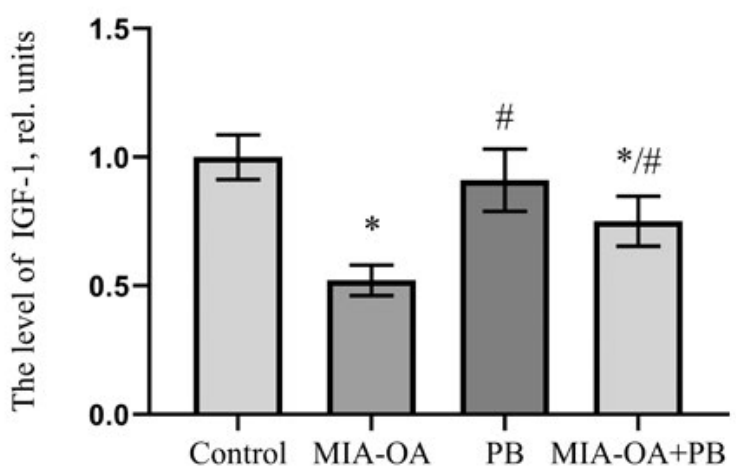

Fig. 3. The levels of anti-inflammatory cytokines IL-4 (A), IL-10 (B), TGF- $\beta$ (C), and IGF-1 (D) in homogenates of knee cartilage of rats with experimental OA, rel. units ( $n=5$ in each group).

Note: $* \mathrm{p} \leq 0.05$, compared to Control group; $\# \mathrm{p} \leq 0.05$, compared to MIA-OA group. 
by macrophages and fibroblast-like synoviocytes [52]. Our results showed the increasing of IL-10 1.3 times in MIA-OA group, compared to Control, (Figure $3 \mathrm{~B}$ ). PB did not cause significant changes in healthy animals (PB group). Administration of $\mathrm{PB}$ to rats with MIA-OA decreased the level of IL-10 to Control values. The observed levels of IL-4 and IL-10 in MIA-OA correlate with the growth of pro-inflammatory cytokines.

Additionally to the anti-inflammatory effects of IL-4 and IL-10, the controversial role of TGF- $\beta$ is actively discussed in the literature. On the one hand, the TGF- $\beta$ supplementation can enhance cartilage repair and is therefore a potential therapeutic tool [53]. On the other, TGF- $\beta$ induces synovial cells to produce inflammatory factors, such as IL-1 and TNF-a, which can further stimulate articular chondrocytes terminal hypertrophy, depositing type $\mathrm{X}$ collagen instead of type II collagen and aggrecan [54]. The TGF- $\beta$ supplementation provides problems in other tissues of the joint and results in the fibrosis and osteophyte formation [55]. The TGF- $\beta$ signaling depends on modulation of the receptor-Smads signaling and plays an important role in both the regulation of chondrocyte differentiation and osteoarthritis development and progression [56]. In this study, the experimental model of OA increased the level of TGF- $\beta 1.7$ times, compared to Control group (Figure $3 \mathrm{C}$ ). The administration of $\mathrm{PB}$ to rats with MIA-OA reduced TGF- $\beta$ 1.2 times but it did not get the level of Control group. Despite an increase in the level of TGFbeta in MIA-OA that correlates with an increased expression of the TGF- $\beta$ gene in cartilage [57], our other study showed negative histological changes [19]. This may indicate insufficient compensatory effort against a significant increase of pro-inflammatory cytokines in the cartilage and blood [58], and may also be associated with fibrosis and cartilage degeneration [59].

IGF-1 plays an important protective and anabolic role during OA. IGF-1 can enhance the cartilage-osteochondral graft for the fibrin regeneration and type II collagen formation [60]. We showed that IGF-1 reduces the loss of chondrocytes and matrix integrity in guinea pig [61]. In this study, MIA-OA caused a decrease in the level of IGF-1 twice, comparing to Control (Figure $3 \mathrm{D}$ ). Administration of PB to animals without MIA-OA did not cause significant changes, compared to Control. PB upregulated the level of IGF-1 in animals with MIA-OA 1.5 times, compared to MIA-OA, however, did not reach the level of Control group. IGF-1 itself cannot induce substantial production of cartilage matrix but it could function in a paracrine and autocrine manner to stimulate matrix synthesis and to inhibit matrix degradation by down-regulating matrix metalloproteinases and inflammatory cytokines [62].

We do not try to "humanize" the intestinal microbiome of rats and the effect of $\mathrm{PB}$ on it. There is a huge difference between rodent and human microbiome diversity; host and microbe have tight relationships [63]. Only clinical trials may show the therapeutic effect of composition during the development of the pathology. The systematic clinical data show controversial effect of $\mathrm{PB}$ on human in wide range of hospital cases, including OA and pain-related conditions [64].

Summarizing the data, administration of different PBs has a modulating effect on the 
cytokines profile in experimental models of OA. Recent studies showed that the administration of $\mathrm{L}$. acidophilus restored the balance between anabolic and catabolic factors in chondrocytes of rats and can alleviate OAassociated pain [65]. Also, reducing serum level of C-reactive protein in rats with OA was shown during the administration of $L$. casei Shirota [66]. The Lyophilized inactivated culture of B. longum decreased the cartilage structure lesions and type ii collagen degradation suggesting a potential effect of $\mathrm{PB}$ on the $\mathrm{OA}$ development [67]. The combination of $\mathrm{PB}$ complex, rosavin, and zinc reduced the expression of IL- 6 and TNF- $\alpha$ in the joints of MIAOA rats [68]. Our previous works showed promising results of combination of $\mathrm{PB}$ and chondroitin sulfate administration on rats model of OA [19].

\section{Conclusions}

We showed the local positive effect of PB in rats with experimental MIA-OA. It was revealed by decreasing levels of pro-inflammatory cytokines in the cartilage homogenate (IL-1 $\beta$, TNF- $\alpha$, IL-6, IL-8, IFN- $\gamma$ ) and normalization of anti-inflammatory cytokines (IL-4, IL-10, TGF- $\beta$, IGF-1). The use of PB in the pathology of the musculoskeletal system is promising to expand existing approaches of the correction and prevention such disorders, including OA. The mechanisms of influence of the microbiome on the development of OA are of great interest and undoubtedly require further study.

\section{Acknowledgements}

The study was supported by budget topic of Ministry of Education of Ukraine 18БП036-02
"Development of methodical recommendations for administration of chondroprotectors and multiprobiotics for correction of joint pathology. Applied scientific research" (2018-2020 academic years).

\section{REFERENCES}

1. Glyn-Jones S, Palmer AJR, Agricola R, Price AJ, Vincent TL, Weinans H, Carr AJ. Osteoarthritis. Lancet. 2015; 386(9991):376-87.

2. Woolf AD, Pfleger B. Burden of major musculoskeletal conditions. Bulletin of the World Health Organization. 2003; 81:646-56.

3. Zhang $W$, Doherty MA, Peat G, Bierma-Zeinstra MA, Arden NK, Bresnihan B, Herrero-Beaumont $G$, Kirschner $S$, Leeb BF, Lohmander LS, Mazieres B, Pavelka K, Punzi L, So AK, Tuncer T, Watt I, Bijlsma JW. EULAR evidence-based recommendations for the diagnosis of knee osteoarthritis. Ann rheum dis. 2010; 69(3):483-9.

4. Berenbaum F. Osteoarthritis as an inflammatory disease (osteoarthritis is not osteoarthrosis!). Osteoarthritis cartilage. 2013; 21(1):16-21.

5. Yang CY, Chanalaris A, Troeberg L. ADAMTS and ADAM metalloproteinases in osteoarthritis-looking beyond the 'usual suspects'. Osteoarthritis Cartilage. 2017; 25(7):1000-9.

6. Greene MA, Loeser RF. Aging-related inflammation in osteoarthritis. Osteoarthritis Cartilage. 2015; 23(11):1966-71.

7. Pandey KR, Naik SR, Vakil BV. Probiotics, prebiotics and synbiotics-a review. J Food Sci Technol. 2015; 52(12):7577-87.

8. Jevsevar DS, Shores PB, Mullen K, Schulte DM, Brown GA, Cummins DS. Mixed treatment comparisons for nonsurgical treatment of knee osteoarthritis: a network meta-analysis. $J$ Am Acad Orthop Surg Glob Res Rev. 2018; 26(9):325-36.

9. Bannuru RR, Osani MC, Vaysbrot EE, Arden NK, Bennell K, Bierma-Zeinstra SMA, Kraus VB, Lohmander LS, Abbott JH, Bhandari M, Dlanco FJ, Espinosa R, Haugen IK, Lin J, Mandl LA, Moilanen E, Nakamura N, Snyd-er-Mackler L, 
McAlindon TE. OARSI guidelines for the non-surgical management of knee, hip, and polyarticular osteoarthritis. Osteoarthritis Cartilage. 2019; S1063458419311161.

10. Wongrakpanich S, Wongrakpanich A, Melhado K, Rangaswami $J$. A comprehensive review of nonsteroidal anti-inflammatory drug use in the elderly. Aging Dis. 2018; 9(1):143.

11. Rogers MA, Aronoff DM. The influence of nonsteroidal anti-inflammatory drugs on the gut microbiome. Clinical Microbiolo Infect. 2016; 22(2):178. e1-178.e9.

12. Savcheniuk O, Kobyliak N, Kondro M, Virchenko O, Falalyeyeva T, Beregova T. Short-term periodic consumption of multiprobiotic from childhood improves insulin sensitivity, prevents development of non-alcoholic fatty liver disease and adiposity in adult rats with glutamate-induced obesity. $B M C$ Complementary Altern Med. 2014; 14(1):247.

13. Kobyliak N, Abenavoli L, Falalyeyeva T, Beregova $T$. Efficacy of Probiotics and Smectite in Rats with Non-Alcoholic Fatty Liver Disease. Ann Hepatol. 2018; 17(1):153-161.

14. Kobyliak N, Falalyeyeva T, Beregova T, Spivak M. Probiotics for experimental obesity prevention: focus on strain dependence and viability of composition. Endokrynol Pol. 2017; 68(6):659-667.

15. Kobyliak N, Falalyeyeva T, Boyko N, Tsyryuk $O$, Beregova T, Ostapchenko L. Probiotics and nutraceuticals as a new frontier in obesity prevention and management. Diabetes Res Clin Pract. 2018; 141: 190-199.

16. Kobyliak N, Virchenko O, Falalyeyeva T, Kondro $M$, Beregova T, Bodnar P, Shcherbakov O, Bubnov R, Caprnda M, Delev D, Sabo N, Kruzliak P, Rodrigo Opatrilova $R$, Spivak $M$. Cerium dioxide nanoparticles possess anti-inflammatory properties in the conditions of the obesity-associated NAFLD in rats. Biomed Pharmacother. 2017; 90: 608-614.

17. Lee WJ, Hase K. Gut microbiota-generated metabolites in animal health and disease. Nat Chem Biol. 2014; 10(6):416.

18. Li Y, Luo W, Deng Z, Lei G. Diet-intestinal microbiota axis in osteoarthritis: a possible role. Mediat Inflamm. 2016; 2016:3495173.
19. Korotkyi O, Vovk A, Kuryk O, Dvorshchenko K, Falalyeyeva T, Ostapchenko L. Co-administration of live pro-biotics with chondroprotector in management of experimental knee osteoarthritis. Georgian Med News. 2018; 279:191-6.

20. Dranitsina AS, Dvorshchenko KO, Korotkyi OH, Vovk AA, Falalyeyeva TM, Grebinyk DM, Ostapchenko LI. Expression of Nos2 and Acan Genes in Rat Knee Articular Cartilage in Osteoarthritis. Cytol Genet. 2019; 53(6):481-488.

21. Korotkyi O, Dvorshchenko K, Vovk A, Dranitsina A, Tymoshenko M, Kot L, Ostapchenko L. Effect of probiotic composition on oxidative/antioxidant balance in blood of rats under experimental osteoarthritis. Ukr. Biochem. J. 2019; 91(6):49-58.

22. Korotkyi O, Vovk A, Galenova T, Vovk T, Dvorschenko K, Luzza F, Abtnavoli L, Kobyiliak N, Falalyeyeva $T$, Ostapchenko L. Effect of probiotic on serum cytokines and matrix metalloproteinases profiles during monoi-odoacetate-induced osteoarthritis in rats. Minerva Biotecnol. 2019; 31(2):68-73.

23. Dobrelia NV, Boitsova LV, Danova IV. Legal basis for conducting ethical expertise in preclinical studies of med-ical products using laboratory animals. Sixth National Congress on Bioethics. 2016; 47.

24. National Research Council. Guide for the care and use of laboratory animals. Washington: "National Academies Press". 2010; 246p.

25. Guzman RE, Evans MG, Bove S, Morenko B, Kilgore $K$. Monoiodoacetate-induced histologic changes in sub-chondral bone and articular cartilage of rat femorotibial joints: an animal model of osteoarthritis. Toxicol Pathol. 2003; 31(6): 619-24.

26. Takahashi I, Matsuzaki T, Kuroki H, Hoso M. Induction of osteoarthritis by injecting monosodium iodoacetate into the patellofemoral joint of an experimental rat model. PloS One. 2018; 13(4): $\mathrm{e} 0196625$.

27. Bradford $M M$. A rapid and sensitive method for the quantitation of microgram quantities of protein utilizing the principle of protein-dye binding. Anal Biochem. 1976; 72(1-2):248-54.

28. Kruger NJ. The Bradford method for protein quantitation. In: The protein protocols handbook. Totowa, NJ: "Humana Press", 2009; pp. 17-24. 
Cytokines profile in knee cartilage of rats during monoiodoacetate-induced osteoarthritis and administration of probiotic

29. Horai R, Nakajima A, Habiro K, Kotani M, Nakae S, Matsuki T, Nambu A, Saiho S, Yayato K, Katsuko S, Oka-hara A, Tanioka H, Ikuse T, Ishii N, Schwartzberg $P L$, Abe R, Iwakura Y. TNF- $\alpha$ is crucial for the development of autoimmune arthritis in IL-1 receptor antagonist-deficient mice. J Clin Investig. 2004; 114(11): 1603-11.

30. Turner MD, Nedjai B, Hurst T, Pennington DJ. Cytokines and chemokines: at the crossroads of cell signaling and inflammatory disease. Biochim Biophys Acta Mol Cell Res. 2014; 1843(11):2563-82.

31. Wojdasiewicz P, Poniatowski ŁA, Szukiewicz D. The role of inflammatory and anti-inflammatory cytokines in the pathogenesis of osteoarthritis. Mediators Inflamm. 2014; 2014.

32. So JS, Lee CG, Kwon HK, Yi HJ, Chae CS, Park JA, Hwang $K C$, Im, SH. Lactobacillus casei potentiates induc-tion of oral tolerance in experimental arthritis. Mol Immunol. 2008; 46(1):172-80.

33. Bradley JR. TNF-mediated inflammatory disease. Rev Med Microbiol. 2008; 214(2):149-60.

34. Yan S, Miao L, Lu Y, Wang L. MicroRNA-506 upregulation contributes to sirtuin 1 inhibition of osteoclastogenesis in bone marrow stromal cells induced by TNF- $\alpha$ treatment. Cell Biochem Funct. 2019; 2019.

35. Daghestani HN, Kraus VB. Inflammatory biomarkers in osteoarthritis. Osteoarthritis Cartilage. 2015; 23(11):1890-6.

36. So JS, Song MK, Kwon HK, Lee CG, Chae CS, Sahoo A, Jach A, Lee SH, Park ZY, Im SH. Lactobacillus casei enhances type II collagen/glucosamine-mediated suppression of inflammatory responses in experimental os-teoarthritis. Life Sci. 2011; 88(7-8):358-66.

37. Goldring $M B$. The role of cytokines as inflammatory mediators in osteoarthritis: lessons from animal models. Connect Tissue Res. 1999; 40(1):1-11.

38. Westacott CI, Sharif M. Cytokines in osteoarthritis: mediators or markers of joint destruction? Semin Arthritis Rheum. 1996; 25(4):254-72.

39. Abdollahi-Roodsaz S, Abramson SB, Scher JU. The metabolic role of the gut microbiota in health and rheumatic disease: mechanisms and interventions. Nat Rev Rheumatol. 2016; 12(8):446.
40. Cleophas MC, Crişan TO, Lemmers H, ToenhakeDijkstra H, Fossati G, Jansen TL, Dinarello CA, Netea MG, Joosten LAB. Suppression of monosodium urate crystal-induced cytokine production by butyrate is mediated by the inhibition of class I histone deacetylases. Ann Rheum Dis. 2016; 75(3):593-600.

41. Dinarello $C A$. Immunological and inflammatory functions of the interleukin-1 family. Ann Rev Immunol. 2009; 27:519-50.

42. Seif F, Khoshmirsafa M, Aazami H, Mohsenzadegan $M$, Sedighi $G$, Bahar M. The role of JAK-STAT signaling pathway and its regulators in the fate of T helper cells. Cell Commun Signal. 2017; 15(1):23.

43. Goldring MB, Otero M, Plumb DA, Dragomir C, Favero M, El Hachem K, Hashimoto K, Roach HI, Olivotto E, Borzi RM, Marcu KB. Roles of inflammatory and anabolic cytokines in cartilage metabolism: signals and multiple effectors converge upon MMP-13 regulation in osteoarthritis. Eur Cell Mater. 2011; 21:202.

44. Sanderson NSR, Puntel M, Kroeger KM, Bondale NS, Swerdlow M, Iranmanesh $N$, Yagita $H$, Ibrahim A, Castro MG, Lowenstein PR. Cytotoxic immunological synapses do not restrict the action of interferon- $\gamma$ to antigenic tar-get cells. Proc Natl Acad Sci. 2012; 109(20):7835-40.

45. Kompanets IV, Korotkiy OG, Karpovets TP, Pilipenko SV, Nikolska VV, Ostapchenko LI, Yankovsky DS. Inter-feron titer and the 2',5'-oligoadenylatesynthetase activity in rat thymus lymphocytes in conditions of Omepra-zol-caused hypergastrinemia. Biopolym. Cell. 2013; 29(1):64-69.

46. Kompanets I, Korotkiy A, Karpovets T, Ostapchenko L, Pilipenko S, Yankovskiy D. The interferon production and 2',5'-oligoadenylate-synthetase activity in rat spleen lymphocytes at hypoacidity evoked by omeprazole injection and at administration of multiprobiotic «SYMBITER $® »$. Curr. Issues Pharm. Med. Sci. 2013; 26(4):398-400.

47. Seder RA, Gazzinelli R, Sher A, Paul WE. Interleukin 12 acts directly on CD4+ T cells to enhance priming for interferon gamma production and diminishes interleukin 4 inhibition of such priming. Proc Natl Acad Sci. 1993; 90(21):10188-92. 
48. O'Neill LA, Kishton RJ, Rathmell J. A guide to immunometabolism for immunologists. Nat Rev Immunol. 2016; 16(9):553.

49. Mobasheri A, Bay-Jensen AC, Van-Spil WE, Larkin J, Levesque MC. Osteoarthritis Year in Review 2016: bio-markers (biochemical markers). Osteoarthritis Cartilage. 2017; 25(2):199-208.

50. Vulpen LF, Popov-Celeketic J, Meegeren ME, Coeleveld K, Laar JM, Hack CE, Schutgens REG, Mastbergen SC, Lafeber, F. P. A fusion protein of interleukin-4 and interleukin-10 protects against bloodinduced cartilage dam-age in vitro and in vivo. $\mathrm{J}$ Thromb Haemost. 2017; 15(9):1788-98.

51. Steen-Louws C, Popov-Celeketic J, Mastbergen SC, Coeleveld K, Hack CE, Eijkelkamp N, Trifonidou M, Spruijt S, Roon JAG, Lafeber FPJG. IL4-10 fusion protein has chondroprotective, anti-inflammatory and potentially analgesic effects in the treatment of osteoarthritis. Osteoarthritis Cartilage. 2018; 26(8):1127-35.

52. Roon JA, Lafeber FP, Bijlsma JW. Synergistic activity of interleukin-4 and interleukin-10 in suppression of in-flammation and joint destruction in rheumatoid arthritis [review]. Arthritis Rheum. 2001; 44:3-12.

53. Davidson EB, Kraan PM, Berg WB. TGF- $\beta$ and osteoarthritis. Osteoarthritis Cartilage. 2007; 15(6):597-604.

54. Shen J, Li S, Chen D. TGF- $\beta$ signaling and the development of osteoarthritis. Bone Res. 2014; 2:14002.

55. Davidson ENB, Vitters EL, Berg WB, Kraan PM. TGF $\beta$-induced cartilage repair is maintained but fibrosis is blocked in the presence of Smad7. Arthritis Res Ther. 2006; 8(3):R65.

56. Kraan PM, Davidson EB, Blom A, Berg WB. TGFbeta signaling in chondrocyte terminal differentiation and osteoarthritis: modulation and integration of signaling pathways through receptor Smads. Osteoarthritis Carti-lage. 2009; 17(12): 1539-45.

57. Korotkyi O, Vovk A, Dranitsina A, Dvorshenko K, Fagoonee $S$, Falalyeyeva T, Ostapchenko L. The influence of probiotic diet and chondroitin sulfate administration on Ptgs2, Tgfb1 and Col2a1 expression in rat knee cartilage during monoiodoacetate- induced osteoarthritis. Minerva Med. 2019; 110(5): 419-24.

58. Korotkyi O, Vovk A, Blokhina O, Dvorshchenko K, Falalyeyeva T, Abenavoli L, Ostapchenko L. Effect of chon-droitin Sulfate on blood serum cytokine profile during carrageenan-induced edema and monoiodoacetate-induced osteoarthritis in rats. Rev Recent Clin Trials. 2019; 14(1): 50-55.

59. Kraan PM. Differential role of transforming growth factor-beta in an osteoarthritic or a healthy joint. $J$ Bone Metab. 2018; 25(2):65-72.

60. Lu S, Lam J, Trachtenberg JE, Lee EJ, Seyednejad H, Beucken JJ, Tabata Y, Kasper FK, Scott DW, Wong ME, Jansen JA, Mikos AG. Technical report: correlation between the repair of cartilage and subchondral bone in an osteochondral defect using bilayered, biodegradable hydrogel composites. Tissue Eng Part C Methods. 2015; 21:1216-25.

61. Wei FY, Lee JK, Wei L, Qu F, Zhang JZ. Correlation of insulin-like growth factor 1 and osteoarthritic cartilage degradation: a spontaneous osteoarthritis in guinea-pig. Eur Rev Med Pharmacol Sci. 2017; 21(20): 4493-50.

62. Chubinskaya S, Hakimiyan A, Pacione C, Yanke A, Rappoport L, Aigner T, Rueger DC, Loeser RF. Synergistic effect of IGF-1 and OP-1 on matrix formation by normal and OA chondrocytes cultured in alginate beads. Os-teoarthritis Cartilage. 2007; 15(4): 421-30.

63. Steves CJ, Bird S, Williams FM, Spector TD. The microbiome and musculoskeletal conditions of aging: a review of evidence for impact and potential therapeutics. JBMR Plus. 2016; 31(2):261-9.

64. Sarah HY, Jernigan JA, McDonald LC. Prevalence of probiotic use among inpatients: a descriptive study of 145 US hospitals. Am J Infect Control. 2016; 44(5):548-53.

65. Lee SH, Kwon JY, Jhun J, Jung K, Park SH, Yang $C W$, Cho Y, Kim SJ, Cho ML. Lactobacillus acidophilus ameli-orates pain and cartilage degradation in experimental osteoarthritis. Immunol Lett. 2018; 203:6-14.

66. Lei M, Guo C, Wang D, Zhang C, Hua L. The effect of probiotic Lactobacillus casei Shirota on knee osteoarthri-tis: a randomised double-blind, placebo- 
Cytokines profile in knee cartilage of rats during monoiodoacetate-induced osteoarthritis and administration of probiotic

controlled clinical trial. Benef Microbes. 2017; 8(5):697-703.

67. Henrotin Y, Patrier S, Pralus A, Roche M, Nivoliez $A$. Protective actions of oral administration of Bifidobacterium longum $\mathrm{CBi} 0703$ in spontaneous osteoarthritis in Dunkin Hartley guinea pig model. Cartilage. 2019; 2019:1947603519841674.

68. Kwon JY, Lee SH, Jhun J, Choi J, Jung K, Cho KH, Kim SJ, Yang CW, Park SH, Cho ML. The combination of probiotic complex, rosavin, and zinc improves pain and cartilage destruction in an osteoarthritis rat model. J Med Food. 2018; 21(4):364-71.

\section{Цитокіновий профіль у колінному хрящі щурів при моноіодоацетат-індукованому остеоартрозі та введенні пробіотику}

О. Г. Короткий, А. А. Вовк, Т. І. Галенова, Т. Б. Вовк, К. О. Дворщенко, Т. М. Фалалєєва, Л. І. Остапченко

Мета. Виявити вплив пробіотику (ПБ) на цитокіновий профіль у колінному хрящі щурів з експериментальним остеоартрозом (ОА). Методи. Тварини 1-ї (Контроль) та 3-ї (ПБ) груп отримували 50 мкл фізіологічного розчину в обидва задніх коліна. Тваринам 2-ї (МIA-OA) і 4-ї груп (МІА-ОА-ПБ) вводили одноразову ін>єкцію 1 мг моноіодоацетату (МIA), розчиненого в 50 мкл сольового розчину, в коліно щурів, після чого МІА-ОА розвивався протягом 28 днів. Введення ПБ здійснювалося щодня протягом 14 днів під час прогресування MIA-OA. Рівні цитокінів (IL-1 $\beta$, TNF- $\alpha$, IL-6, IL-8, IFN- $\gamma$, IL-4, IL-10, TGF- $\beta$, IGF-1) в гомогенатах хряща вимірювали за допомогою імуноферментного аналізу (Biotrak ELISA System, GE Healthcare, USA). Результати. MIA-OА викликав підвищення рівнів IL$1 \beta$, TNF- $\alpha$, IL-6, IL-8, IFN- $\gamma$, IL-10, TGF- $\beta$, знижував рівень IGF-1 і не змінював рівень IL-4 порівняно 3 контролем. ПБ під час МІА-ОА підвищував рівень IGF-1, зменшував рівні IL-1 $\beta$, TNF- $\alpha$, IL-6, IL-8, IFN- $\gamma$, TGF- $\beta$, порівняно 3 MIA-OA, але дані показники не досягали контрольних значень (на відміну від IL-4 i IL-10, які були рівні контрольним). Висновки. MIA-OA викликав значні зміни рівнів досліджуваних цитокінів у колінному хрящі. Застосування ПБ справляло місце- ву протизапальну дію на хрящову тканину щурів 3 MIA-OA.

Кл юч о в і сл о в а: остеоартроз, цитокіни, фактори росту, пробіотик, хрящ

\section{Цитокиновый профиль в коленном хряще крыс при моноиодоацетат-индуцированном остеоартрозе и введении пробиотика}

А. Г. Короткий, А. А. Вовк, Т. И. Галенова, Т. Б. Вовк, К. А. Дворщенко, Т. Н. Фалалеева, Л. И. Остапченко

Цель. Выявить влияние пробиотика (ПБ) на цитокиновый профиль в коленном хряще крыс с экспериментальным остеоартрозом (ОА). Методы. Животные 1-й (Контроль) и 3-й (ПБ) групп получали 50 мкл физиологического раствора в оба задних колена. Животным 2-й (МИА-ОА) и 4-й групп (МИА-ОА-ПБ) вводили однократную инъекцию 1 мГ моноиодоацетата (МИА), растворенного в 50 мкл солевого раствора, в колено крыс, после чего МИА-ОА развивался в течение 28 дней. Введение ПБ осуществлялось ежедневно в течение 14 дней во время прогрессирования МИА-ОА. Уровни цитокинов (IL-1 $\beta$, TNF- $\alpha$, IL-6, IL-8, IFN- $\gamma$, IL-4, IL-10, TGF- $\beta$, IGF-1) в гомогенатах хряща измеряли с помощью иммуноферментного анализа (Biotrak ELISA System, GE Healthcare, USA). Результаты. МИА-ОА вызывал повышение уровней IL-1 $\beta$, TNF- $\alpha$, IL-6, IL-8, IFN- $\gamma$, IL-10, TGF- $\beta$, снижал уровень IGF-1 и не изменял уровень IL-4 по сравнению с контролем. ПБ вовремя МИА-ОА повышал уровень IGF-1, уменьшал уровни IL-1 $\beta$, TNF- $\alpha$, IL-6, IL-8, IFN- $\gamma$, TGF- $\beta$, по сравнению с МИА-ОА, но не достигал контрольных значений (в отличие от IL-4 и IL-10, которые были равны контрольным). Выводы. МИА-ОА вызывал значительные изменения уровней изучаемых цитокинов в коленном хряще. Применение ПБ оказывало положительное местное противовоспалительное действие на хрящевую ткань крыс с МИА-ОА.

Кл юч е в е с л ов а: остеоартроз, цитокины, факторы роста, пробиотик, хрящ

Received 26.09.2020 